\title{
ヒューマンガイダンスを用いた駐車支援システム
}

\author{
非会貣ワダ マサキ* 非会貝 尹 康学监** \\ 正 員 橋本 秀紀*
}

\section{Parking Assistance Systems using Human Guidance}

Massaki Wada*, Non-member, Kang Sup Yoon**, Non-member, Hideki Hashimoto*, Member

This paper dicusses the problem of parking assistance system development. Firstly, we propose the driver assistance systems general architecture based on path planning and human interface modules. A path generation method based on parking possibility area is developed for the parking assistance systems. The human interface designed for the parking assistance systems is then described. A prototype of the parking assistance systems based on the proposed architecture and approaches have been constructed. Proposed algorithms and implementation solutions in the prototype construction are described. The lane and row parking experimental results obtained with the prototype systems are also shown.

キーワード：駐車支援システム，ヒューマンガイダンス，経路生成，ヒューマンインターフェース，ITS

Keywords: Parking Assistance System, Human Guidance, Path Planning, Human Machine Interface, ITS

\section{1. まえがき}

自動車, 道路, 人をシステム化するITS (Intelligent Transportation Systems) が我々の身近なものになってきてい る。また, 社会的な要求として, ドライバの負担を減らし安 全性を高莄運転支援システムの必要性が指摘されている。

筆者らはレベルの異る複数タスクを含んだ運転支援シス テムの研究を進めており，特に駐車支援システムのアーキ テクチヤ，設計等について検討を行っている。駐車は，回 転半径が短く車両の方向変化が大きいことに加え, 後進動 作が含まれており，周辺車両との衝突の呵能性も高い。そ のため, 周辺監視能力が未熟である初心者にとっては運転 操作の中で最も困難な操作の一つである。また, ペーパー ドライバや高齢者ドライバの増加に伴い, 駐車支援システ ムの必要性はますます高まってきている。本論文では運転 支援システムの一環として，ヒューマンガイダンスを用い た駐車支援システムに関する研究成果を報告する。

\footnotetext{
*東京大学 生産技街研究听 第 3 部

T 153-8505 東京都目黑区駒場 4-6-1

The 3rd Department, Institute of Industrial Science, University of Tokyo

4-6-1, Komaba, Meguro-ku, Tokyo 153-8505

**大邱大学 自動車産菜機械工学部

干712-714 鹿尚北道慶山市珍良邑内里里 15

The School of Automotive, Industrial, and Mechanical Engineering, Daegu University

15, Naeri, Jinryang, Gyeongsan, Gyeongbuk, 712-714
}

最初に駐車支援システムを概観し，ヒューマンインター フェースと経路生成アルゴリズムによるヒューマンガイダ ンスシステムアーキテクチャを提案する。さらに，実際の 駐車支援システムの設計, システム赛現のためのハードウ エア，アルゴリズムについて述べ, 実験結果を示す。

\section{2. 駐車支援システム（Parking Assistance Systems)}

システムでどのような通信（車々間・路車間），車雨・駐 車場でどのようなセンサシスデムが使用されているか（ま たは使用されていない加によって様々な駐車支援システ ムが考元られる。本駐車支援システムは駐車場管理システ ム (Parking Administration System), 車両センサシステ ム (Vehicle Sensing System)，ヒューマンガイダンスシス テム(Human Guidance System) の三つの要素から構成 される。図1に駐車支援システムに扔ける各システム間の 情報の流れを示す。

この構成のシステムで駐車場の入口から駐車スペースま でガイドする時のイメージを図 2 に示す。駐車場の入口か ら駐車スペースまで車雨をガイダンスする手順は次の通り である。

Step 1 駐車場の入口で駐車場管理システムが車両に駐 車情報を提供

Step 2 駐車場の入口から駐車スペース前までのガイダ ンス 


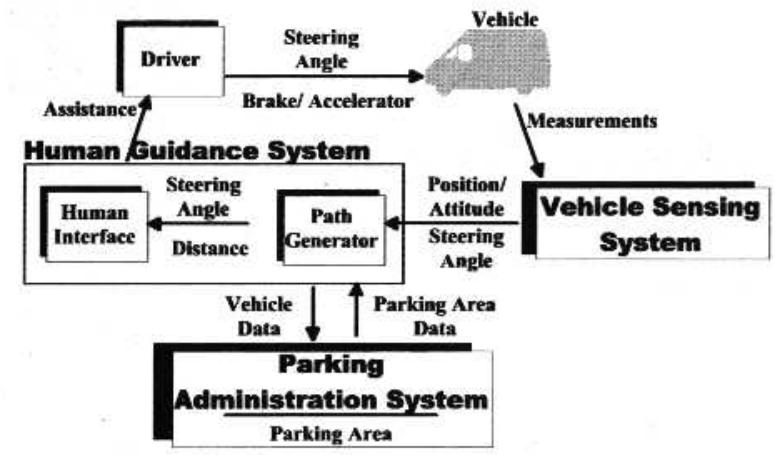

図 1 駐車支援システムでの各システム間の情報 の流れ図

Fig. 1. Information flow between the systems of parking assistance system.

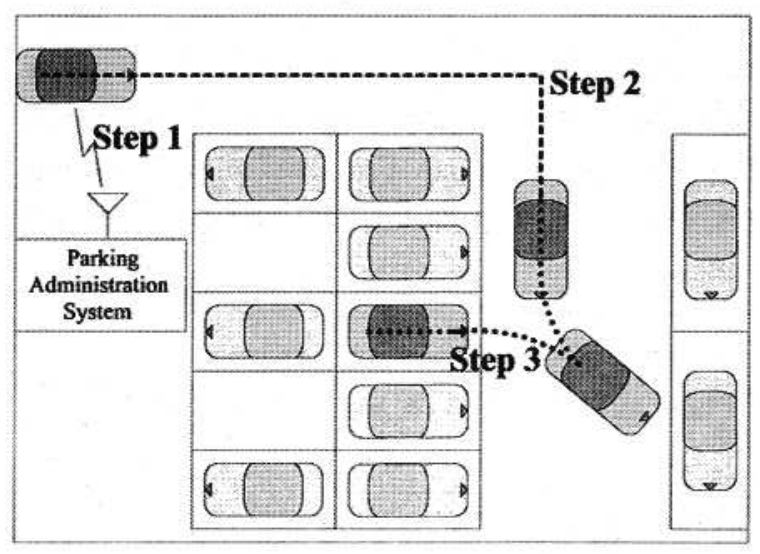

図 2 車両ガイダンスのイメージ図

Fig. 2. Image of vehicle guidance.

Step 3 駐車スペース前から駐車スペースまでのガイダ ンス

駐車支援システムは, 全てを自動で行なう自動駐車シス テム(1) (2) (3) と比較するとシステムの中にドライバを含む という大きな違いがある。ドライバを含むことにより，特 間遅延, 経路のずれ及びドライバ自身が感じるの不安感等 の問題が予想される。時問遅延とはドライバが駐車支援シ ステムから提供される情報を受け取ってから実際に運転動 作を行うまでに要する時間の遅れである。経路のずれは， 時間荤延, 不正確なハンドル操作（ステアリング), 急激な アクセル及びブレーキ操作により発生する。また，ドライ バは主としてモニタおよび音声によるガイダンスにのみ依 存して運転することになるので, 後進時に直接後方を見な いことによる不安感を持つ。そのため，駐車支援システム の設計時にはドライバの操作誤差および不安感を軽減でき るヒューマンガイダンシステムが要求される。

すでに製品化されている駐車支援システムは駐車プロセ スの一部 (Step 3 のなかのバック動作等) のみを支援する。 これに対して, 本研究では異なる複数タスクを含んだ連転 支援システムの検討の一環として上述した全ての Step を 支援するシステムの実現を武みた。

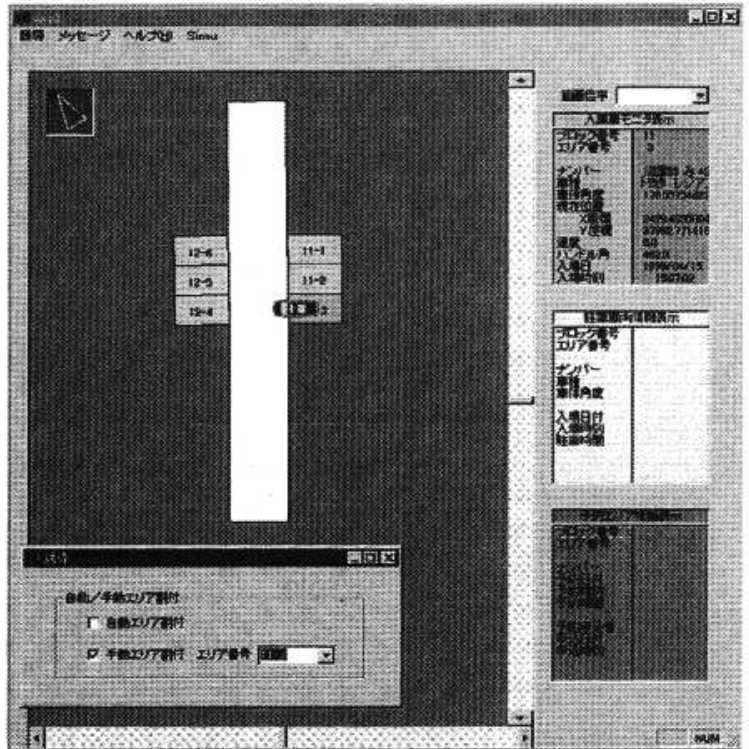

図 3 駐車場管理システムの画面表示

Fig. 3. Display of parking administration system.

表 1 センサシステムの仕様

Table 1. Sensors spec.

\begin{tabular}{|c|c|c|}
\hline センサ & $\begin{array}{l}\text { サンブリング } \\
\text { 時間 }\end{array}$ & 仕样 \\
\hline DGPS & $200 \mathrm{~ms}$ & 精度：RMS $15 \mathrm{~cm}$ \\
\hline INS & $50 \mathrm{~ms}$ & $\begin{array}{l}3 \text { 軸ジャイロ (ドリフト } 1 \sigma: \\
\left.3^{\circ} / h\right) \text { と } 3 \text { 軸 サーボ加速度 } \\
\text { 計 }(\text { トリリフト } 1 \sigma: 10 \mathrm{mg})\end{array}$ \\
\hline 車輸 エンコータ & $50 \mathrm{~ms}$ & 90 スリット/回転 \\
\hline ステデリングセンサ & $50 \mathrm{~ms}$ & 96 スリット/同転 \\
\hline
\end{tabular}

\section{3. 駐車場管理システム及びセンサシステム}

〈3-1〉 駐車場管理システム 駐車場管理システムは騂 車場を管理し，駐車場へ入る車両に空き駐車スペースを割 り当てる。また, 駐車支援に必要な駐車場の状態つまり䭼 車スペースの絶対位置と広さ, 駐車スペース前方の道路幅 を車両に提供する。

本システムでは果両が駐車場に進入したことを光電管で 検知することにより，ヒューマンガイダンスシステムとの 通信を開始する。また管理システムの画面から予約状況や 人庫している車両デー夕等が碓認可能である。図 3 は, 駐 車場管理システムが表示する画面の一例である。

〈3·2〉 センサシステム センサシステムは, 複数の センサと車両の状態を推定する推定アルゴリズムにより構 成される。

本システムで使用するセンサは DGPS (Differential Global Positioning System), INS (Inertial Navigation System)，ステアリング角度センサ, 車輪角速度センサで ある。DGPS アンテナと INS は後輸軸の中心の垂直線上 に設置する。本システムで仕様したセンサの仕様を表 1 に 示す。 
複数のセンサデータから嗃精度かつロバストに車雨状態 推定值を得るためには，データ融合アルゴリズムが必要にな る。融合アルゴリズムでは内界センサのキャリブレーショ ン, 車輸半径の推定, 非同期データへの对応等を考慮する 必要がある。以上の問題を考摩し，車两の状態（釈対位置， 姿勢，ステアリング角）を実封間で推定するためにMulti-

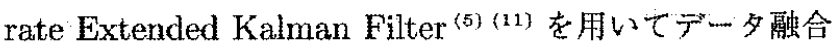
を行った。

\section{4. ヒューマンガイダンスシステム}

ヒューマンガイダンスシステムでは，センサシステムと 駐車管理システムから情報を取得し運転操作情報を生成し, この操作情報をドライバに提倛する。

本諭文では経路生成アルゴリズムとヒューマンインター フェースに基づくヒューマンガイダンスシステムアーキテ クチャを提案する。このアーキテクチャを用いることで, 制 御ループにドライバを含むために発生する問題，センサの 不確実性による問題を補償したシステムが構筑可能になる。 本章では駐車支援システムに招いてこのアーキテクチャに よる設計とその実現をホす。

経路生成アルゴリズムは車雨の状態，車雨形状，及び駐 車場管理システムから得られる駐車場情報を用いて駐車天 ペースまでの経路及び薑転操作情報を生成する。この情報 がヒューマンインターフェース部分を介してドライバに提 供される。ドライバがヒューマンインターフェースの指示 通りに車雨を操作することにより，車雨は駐車スペースま で安全にガイダンスされる。

一般的なとェーマンガイダンスシステムでは, 経路生成 と運転操作の判断に関する人間のスキルと機械知能の共同 作業によってタスクが害現される。この作紫ではどの程度 人間の知能を使用するかによって以下のガイダンス方法が 考えられる。

1) ドライバの知能を全〈利用せず，ドライバをアク チュエータとして考える方法。

2) 駐莗支援システムは駐車スペース位置と周辺状態 を提供するだけで, 経路生成と運転操作をドライバ の知能と技街に依存する方法。

3） 1)と 2)の間で，ドライバの知能と技術をある程 度用いる方法。

経路生成とヒューマンインターフェースによる構成を実 現するための第一段階は各ステップで使用されるガイダン ス方法の決起である。ドライバへの定嘈的・高精度なガイ ダンスの必要性, 妥些性等がガイダンス方法選択の主な基準 となる。ドライバの操作畤に必要以上に定量的かつ高精度 な指示が施されるとドライバの注目がヒューマンインター フェースに集中する。この場合ガイダンス以外の事象に対 してドライバ認識能力の低下が扢こる。従って定量的・高 精度なガイダンスの埒入は慎重に行う必要がある。

駐車場の入口から騂車久ペース前までのStep 2 におけ
る低速走行ではドライバに定量的・高精度なガイダンスを 狏す必要がない。またここでは周辺視野を䠅かにせずドラ イバ自身が経路生成と運転操作を行うのが望ましいため2) の方法でガイダンスする。

Step 3 では椱雑かつ离精度な操作が必要であり，1）と 3) の雨ガイダンス方法が造しているといえる。しかし，本シ ステムでは离龄者や初心者ドライバの支援も目的としてい ること侤慮して，1）の方法を採用する。

第二段階は，各ステップで選択されたガイダンス方法を 実現する経路生成アルゴリズムとヒューマンインターフェ スの設計および䡔築である。以降駐車支援シスデムにおけ る経路生成とヒューマンインターフェスの設計と構築につ いて述べる。

〈4.1〉経路生成 経路生成アルゴリズムは各ステップ ごとに異なるものが必要である。Step 2 ではカ-..゙ビ等で 使用されている経路生成アルゴりズムを直接用いた。この 手法は一般的なアルゴリズムの伈用であるだ本論文では 晋及しない。

Step 3 における経路生成アルゴリズムは, 駐車場管理シ ステムから提供される駐車場情報とセンサシステムから提 供される車雨の情報を利用して，車雨を駐車スペース前か ら駐車スペースまでガイドするため，経路および揮転操作 命令を生成する。

このステップの経路生成では, 種々の物理的な制約条件 を考慮する必要がある。一つは経路生成に扮计名車雨の運 動モデルの考慮である。駐車時は車雨が低速走行であるた め, 幾湖学的関係は Ackermann Steering Geometry ${ }^{(9)}$ で 表現できる。すなわち，回転中心が後輪軸の延長線上にあ ると仮定して，後輪軸の中心位置を基準しして経路及び運 転操作命令 (ステアリング角度，移動距離）を計算する。

また，駐車スペースの幾何学的な物理拘束も考慮する必 要がある。駐事支援シスデムでは経路生成時に駐車スペー ス及び駐車スペース前の道路においてセンサシステムの精 度を考琶した危険領域を設定する。このように危険領域を 設芫し駐車操作に使用可能なスペースを限定することで, 生成される経路が周国の駐車スペースに侵大しないように する。

従来の多くの手法で生成される経路は，ドライバが追従 するには困難が伴う。これは，従来の手法ではステアリン 多每度制御指令と速度制御指令に対し同時に追従する必要 があるためである。そこで，本ガイダンスシステムではス テアリング角度制御と前後進の距離制御を交互に行うよう な経路生成方法を採用する。つまり，ステアリング操作を 走行中には行わず，静止中にのみ行うような経路を使用す る。このような経路は直線と炣だけで搆成される。

以上の条件を考慮した経路生成方法を自動駐車システム や移動口决ット等で使用されている様々な方法 (ポテンシャ

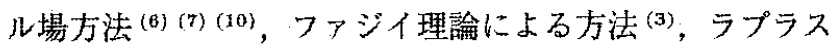
方程式による方法 ${ }^{(8)}$ ) を用いて実現することが考えられる。

しかし，駐車支援システムの経路生成では従来の要求に 
加えて，人間が介在するため発生する複数の要因を考慮す る必要がある。まず人間がアクセルとブレーキ操作で速度 制御を行うことは非常に難しく, 従来の手法に必要な速度 制御の実現は不可能である。また自動・自律システムでは 実時間フィードバックを用いた経路追従のために経路が生 成されている。本システムでは人間の遅延と人問のミスが 存在するため, 実時間フィードバックの実現が不可能であ る。そのため本システムでの経路生成の役割は，追従のた めの経路を生成することではなく，運転操作指示を生成す るためのものとなる。

さらに人間が介在しているため, 従来のアルゴリズムで は考虑されていない新たな要求も加わる。これはすなわち, ドライバの操作エラーが頻繁に発生しても，必要最小限の 操作で駐車を実現する操作性（ドライバビリティ）向上に 関する要求である。

以上駐車支援システム経路生成の要求について述べた。 問題の物理的条件, 経路生成の役割, 速転性の実現全てを考 慮したアルゴリズムを従来の万法の延長として実現するの は困難である。以上の問題を解決するために後述する Parking Possibility Region (PPR) を定義し，このPPRを介 した新たな経路生成手法を提䋈する。本アルゴリズムは人 間へのガイダンスを目的とし，かつ人間が介在するシステ ムの特徵を生かした独自の経路生成手法である。

本論文では駐車スペースの中心線を基潐にした車体角度 を使用する。ある車体角度から一回のステアリング角度制御 指令と距離制御指令で, 駐車スペースの中心線に到達可能な 後输軘中心位置の領域を Parking Possibility RegionPPR と定義する。定義から各PPR に対㣽て一つの車 体角度が存在する。以降この角度を PPR 角度とよぶ。

図 4 と図 5 に直角 (横列) 駐車と平行 (縦列) 臨車にお いて, PPR 角度が $45^{\circ}$ の場合の PPR を示す。車体角度と PPR 角度, 後輸軸中心位置と PPR 重心点がそれぞれ一致 した車両も示す。また駐車スペース中心線までの経路とこ の経路による車屾最終位䝵も示す。なお PPR 演算の詳細 は付録 1 に直角駐車のPPR 演算方法として示す。

車両の理想的な駐車完了位置は, 眐車スペースの中心線 上で駐車することである。そして, 車雨が PPR に到達す れば，以後の経路生成及びガイダンスは簡単に行うことが できる。

しかしガイダンスのため車両がPPR内の点へ到達可能で あるか，または車両が PPR にあるかを判断するには PPR 角度を考虑する必要がある。ある PPR 内の点へ到達可能 であるためには現在の位置・姿勢から車両位置が PPR 内 の点, 車体角度がこの PPR の PPR 角度という状怎にな るまでの経路が存在する必要がある(現在の車両位置から PPR 内の点までの経路が存在することは十分条件でなく, 到達点での車体伤度も考慮する必要があることに注意)。同 様に車両がある PPR にあるためには車屾位沿がこの PPR 内であり，かつ車体角度がこの PPR に対応する PPR 角度 でなければならない。

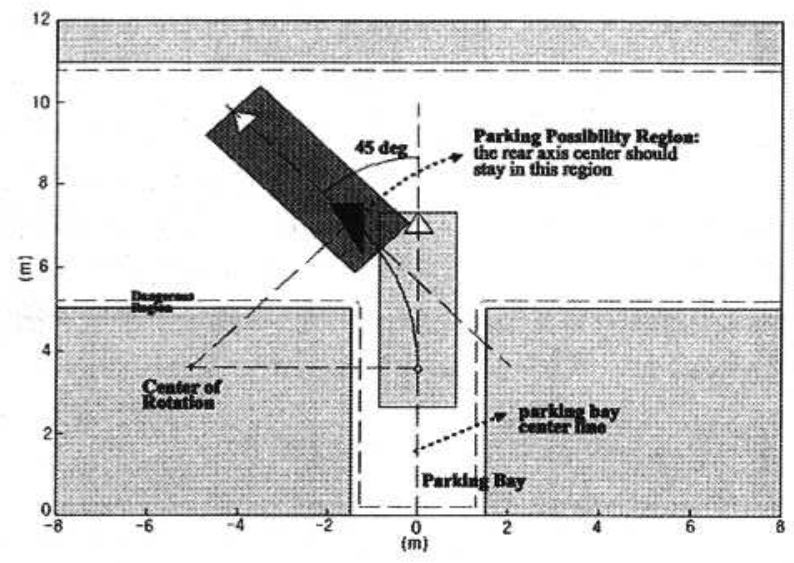

図 4 直角 (横列) 駐車の場合の PPR

Fig.4. Parking possibility region in case of row parking.

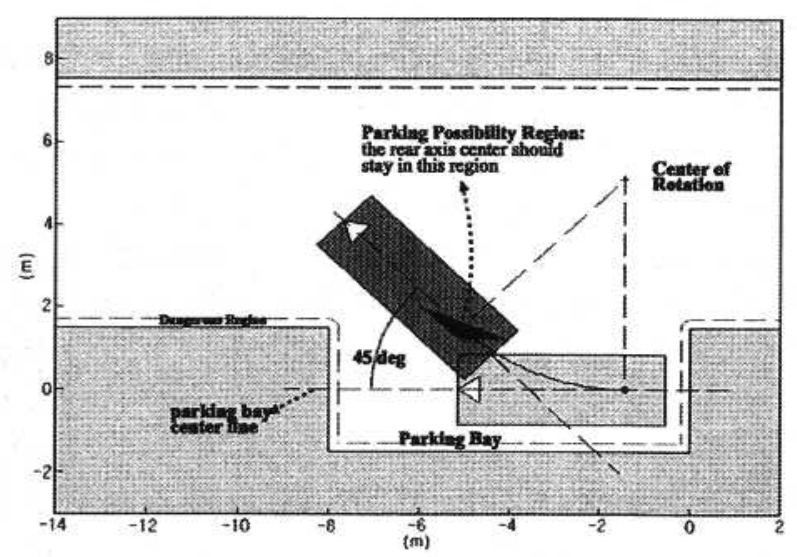

図 5 平行 (縦列) 駐車の場合の PPR

Fig. 5. Parking possibility region in case of lane parking.

経路生成アルゴリズムは以下の通りである。

\section{1) 直角 (横列) 駐車の場合}

(1) 䑕車スペース前の初期停止位置に扔いて $1^{\circ}$ きざ みで PPR 伤度が $1^{\circ}$ から $89^{\circ}$ までの PPR の重心点 を求める。

(2) 初期停止位置から直線と円弧からなる経路で到達 できる重心点 (PPR 1 重心点) を到達点として(1)か ら選択して経路を生成（複数の到達可能な重心点の 中で最小 PPR 角度の重心点を選択)。

（3）（2)に基づき直進し停止した位置から新たに円弧だ けで到達できる PPR (PPR 2) 内の到達点を選択 し, この到達点までの経路を生成する (複数 PPR 内 の異なる到達可能な点の中から到達点を選択する。 到達可能な点とこの点に対応する PPR 重心点の間 の距離が最短である到達点を選択)。

(4) (3)に基づきハンドルを切り円弧によって到達した 停止位置がいずれの PPR 内（PPR 3) にあれば煁 車スペースの中心線までの円弧経路を生成する。停 

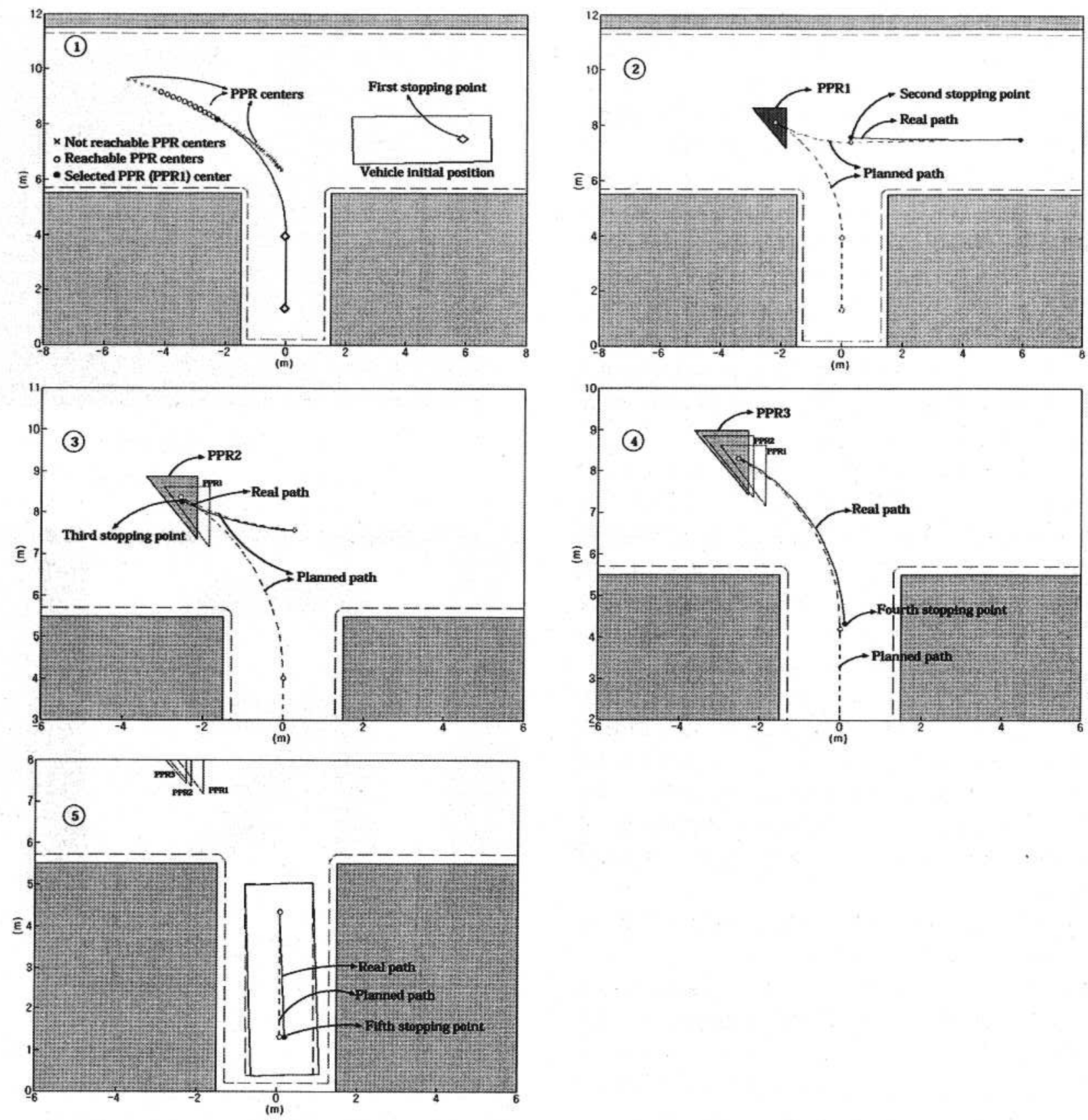

网 6 PPRによる経路生成の夰ステップ（シミュレーション結果）

Fig. 6. Steps of path planning using PPR (Simulation Results).

止位置が PPR 外にあれば，駐車スペースの中心線 を行き過ぎずに駐車スベース内に最樑く入る経路 を生成。その後(3)から反復。

(5) 駐車完了位置までのガイダンス及び駐車完了判断。 2) 平行 (縦列) 駐車

(1) 駐車スペース前の初期停止位整において $1^{\circ}$ きさ みで PPR 㑇度が $1^{\circ}$ から $89^{\circ}$ までの PPR の重心点 を求める。

(2) 初期停止位置から円弧（前進）と円弧（後進）で 到達できる重心点 (PPR 1 重心点) を到達点として (1)から選択して経路を生成（複数の到達可能な重心
点の中で最小 PPR 角度の重心点を選択)。

(3) (2)に基づきハンドルを切り円弧（前進）によって 到達した停止位置から新たに円瓜 (後進) だけで到 達できる PPR (PPR 2) 内の到達点を選択し,この 到達点までの経路を生成する（複数 PPR 内の異な る到達可能な点の中から到達点を選択する。到達可 能な点とこの点に対応する PPR 重心点の間の距離 が最知である到達点を選択)。

(4) (3)に基づきハンドルを切り円弧（後進）によって 到達した停止位置がいずれの PPR内（PPR 3）に あれば眭車スペースの中心線までの円弧経路を生成 
する。停止位置が PPR 外にあれば, 駐車スペース の中心線を行き過ぎずに駐車スペース内に最も深く 入る経路を生成。その後(2)から反復。

(5) 䭼車完了位置までのガイダンス及び駐車完了判断。 図 6 に上記アルゴリズムを実施したときの各ステップに それぞれ対応した図を示す。ただし，コンセプトをわかり やすく表現するためにシミュレーション結果を用いている。

(1)では各 PPR 重心点が演算される。(1)の図には経路生 成のために選択されたPPR（PPR 1) の重心点, 直線と 円弧で到達できる PPR 重心の一部, 直線と円弧で到達で ないPPR 重心点の一部を示した。PPR 重心点に到達可能 であるためには停止した位置・姿勢から車両の位置が重心 点・車体角度が PPR 角度の状態になるまでの経路が存在 しなければならない。

(2)の図では選択された PPR 中心点を用いて生成された 経路と実際に走行した直線経路を示した。

(3)の図では直線移動中に誤差が発生し, 新たに円弧だけ で到達できるPPR（PPR 2）内の到達点が選択された場 合を示している（この選択にも PPR 角度を考虑する必要 がある）。またこの新たに選択されたPPR 内の到達点を用 いて生成された経路と実際に走行した円弧経路も示した。

(4)の図では円弧で移動している間に誤差が発生し, 前ス テップで選択された PPR（PPR 2) と異なったPPR 内 （PPR 3）に停止した場合を示している。このステップで は, 現在車両がPPRにあるかをPPR 角度を考慮して判断 することが必要になる。車両が椡達した PPR(PPR 3) と, これを用いて生成された経路及び実際に走行した円弧経路 も示した。

(5)の図では駐車完了位置まで生成された経路と実際に走 行した経路を示している。

〈4·2〉 ヒューマンインターフェース 直観的なガイダ ンスを実現するため, モニ夕による視覚情報提示スピーカに よる音声情報提示を用いたマルチモーダルなヒューマンイ ンターフェースを構成した。モニタを視覚インターフェー ス, スピーカを聴覚インターフェースとして用いたヒューマ ンインターフェースを構成した。これらのインターフェー スを用いて，駐車場の入口から駐車スペース前までのガイ ダンス時（Step 2) は睡車場管理システムから提供される 駐車スペース場情報とセンサシステムから提供される車両 の現在位置 ·姿勢情報をドライバに伝達し, 卧車スペース 前から駐車スペースまでのガイダンス時（Step 3）は経路 生成アルゴリズムで生成された経路とより詳細な運転操作 情報をドライバに伝達する。

ターダットとするコーザに対して最適であり，かつ，提 案するガイダンス方法に適したインターフェースを得るた め, 伝達すべき情報が直感的かつ正確に伝わるか, そして 定量的な指示に対して精度のよい操作が得られるか等の観 点に基づき, 実験からのフィードバックを評価しながらイ ンターフェースの開発を進めた。本章ではこの開発手法で 棈築されたヒューマンインターフェースについて述べる。

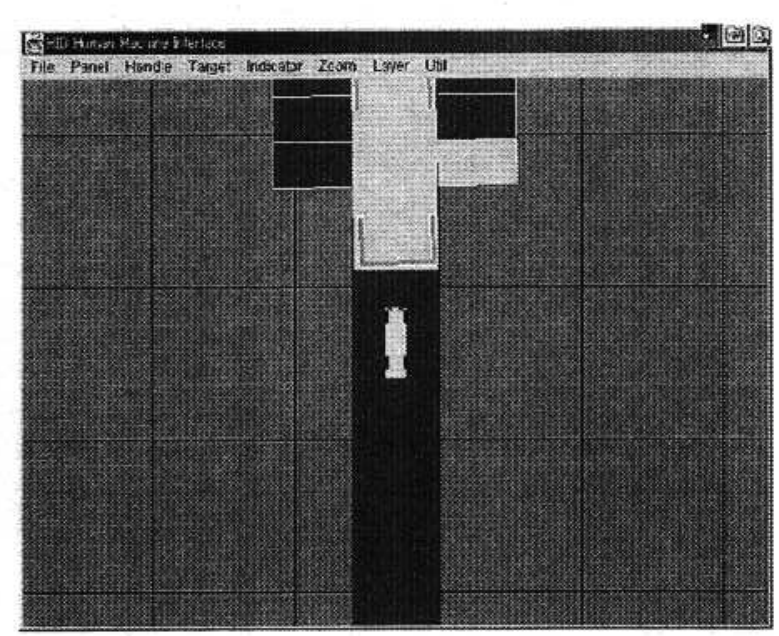

図 7 Navigation mode $の$ 画面

Fig. 7. Screen for navigation mode.

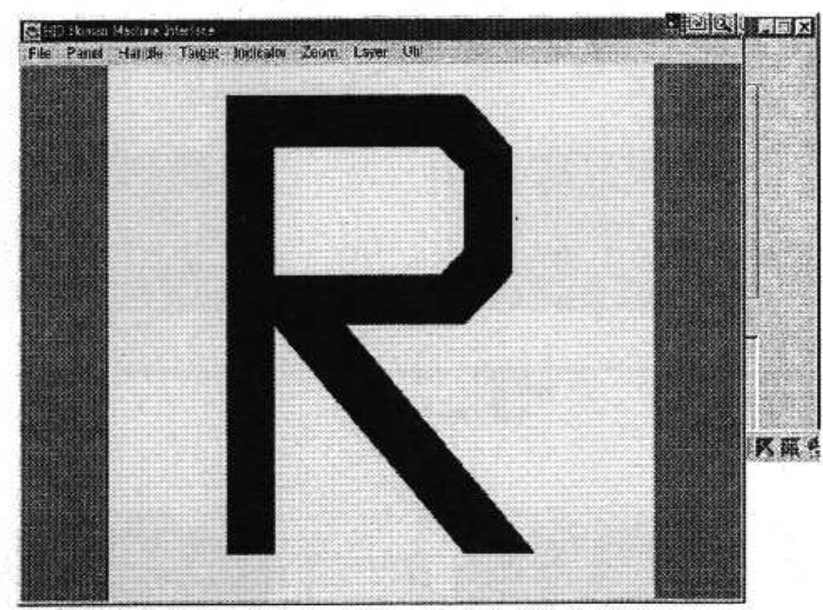

図 8 ギア変換時の画面

Fig. 8. Screen forgear change mode.

ヒューマンインターフェースには次の 4 つのモードがあ る。駐車場の入口から駐車スペース前までのガイダンス時 (Step 2) は Navigation Mode を使用し, 駐車スペース前 から駐車スペースまでのガイダンス時（Step 3）は Gear Change Mode, Handle Operation Mode, Target Position Modeを使用する。

Navigation Mode 駐車場の入Пから眐車スペース 前の初期停止位置までのガイダンス時（Step 2）に使用す る。駐車場, 割り当てられた駐車スペース, 現在の車両位 置, 初期停止領域を表示し，ドライバを䑕車スペース前ま でガイドする。この時のヒューマンインターフェースの画 面を図 7 に示す.

Gear Change Mode 初期停止位㯰及び目標位置 に到達していれば, 次の経路で入れるギアを表示する。こ の時のヒューマンインターフェースの画面を図 8 に示す。 ただし，次のギアが現在のギアと同じ場合は表示しない。 同時に，「Reverse ギアを入れて下さい」というような音声 による支援も行なう。初心者の場合, ギアの変換を忘れる 


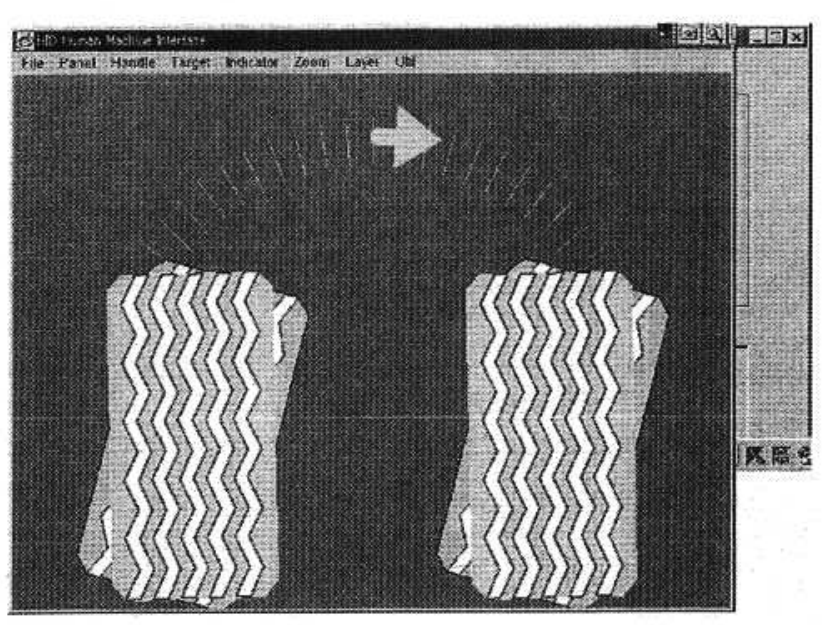

図 9 ハンドル操作時の画面

Fig. 9. Screen forhandle operation mode.

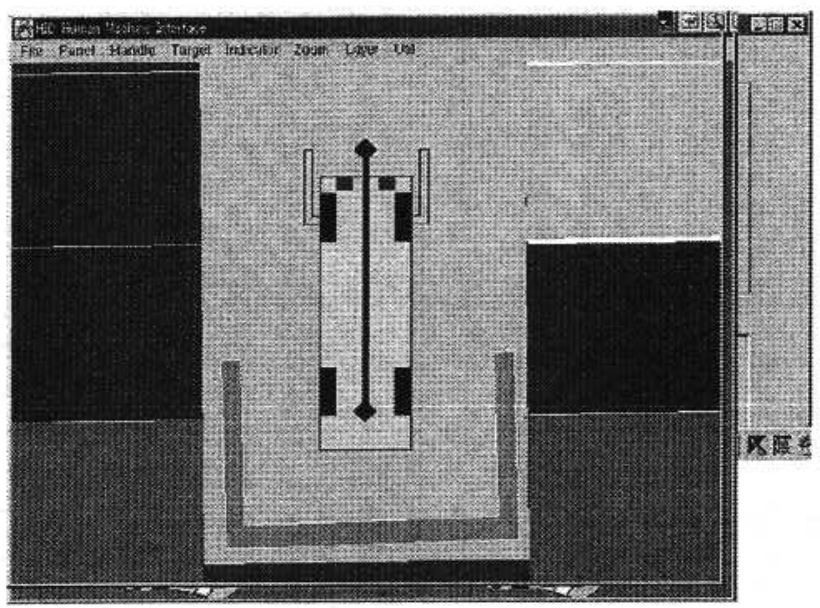

図 10 日標点まで移動時画面

Fig. 10. Screen for moving to target position.

ことが多く，これを防止するため変換するべきギアを表示 する。また駐車終了指令もパーキングギアを指示すること によってこのモードで示される。

Handle Operation Mode ハンドル角度（ステア リング角度）は，アニメーションを利用してタイヤの現在 の角度と目標角度を重ねて示し, 上段に久印で回転方问と 回転量を示す。アニメーションで表示する際，ハンドルで はなくタイヤを利用したのは, ハンドル角度が 1 回転以上 の場合には表現に困難が生じるためである。夕イヤの方向 は車両の進行方向とほほ同じであるため,ドライバが次の 動作を理解しやすい。この時のヒューマンインターフェー スの画面を図 9 に示す。同時に音声支援で「ハンドルを右 に回して下さい」という指示が行われる。

Target Position Mode ギアとハンドルの操作が 終わり次第, 車両の現在位置と目標位置を表示し, 車雨を目 標位置までガイダンスする。この時のヒューマンインター フェースの画面を図 10 に示す。このモードでは車出が移 動し,ドライバが画面に集中して周辺監視, 速度把握等を踈
かにすることは非常に危険である。このため特にこのモー ドの音声インターフェースは重要である。音声によるイン ターフェースは「前進して下さい, 目標まで $3 \mathrm{~m}, 2 \mathrm{~m}, 1 \mathrm{~m}$ 」 のような指示と同時にブザー音を利用して目標位置までの 残りの距離を知らせる。残りの距離が短くなるにつれてブ ザー音の間隔を短くし，ドライバの距離感覚を補助する。

\section{5. システム構成と実験}

駐車支援システムを実現するため構成したシステムを 図 11 に示す。車両側では経路生成及び位置推定用 PC と ヒューマンマシンインターフェース用のPC 2 台を用いる。 車載 PC は LAN で接続されている。駐車管理 PC と車載 $\mathrm{PC}$ は, 無線 LAN を介して接続され,ソフトウェアレベルで は高速な Java 用分散オブジェクト HORB (Hirano Object Request Broker) (12) を用いて通信を行なっている。

実験に使用した車両 Toyota-JZS147を図 12 に示す。車 両の外形は全長 $4695 \mathrm{~mm}$, 全幅 $1695 \mathrm{~mm}$ でありまたホイー ルベースは $2985 \mathrm{~mm}$, 最小回転半径は $(4200 \mathrm{~mm})$ であり 一般の乘用車と比較して大きいため, 駐車操作はより困難 である。

想定した駐車場のスペースでシミュレーションを行なっ て位置姿勢精度がそれぞれ $10 \mathrm{~cm}, 1^{\circ}$ 以上必要であるこ とが確認された。この精度の実現のために複数センサと, Multirate Extended Kalman Filter による車両位置姿勢 推定アルゴリズムで構成したセンサシステムを用いた。

前述の駐車支援システムの妥当性を検討するために, 直 角 (横列) 駐車及び平行 (縦列) 駐車を対象として実験を 行った。直角駐東実験は全長 $5500 \mathrm{~mm}$, 全幅 $2500 \mathrm{~mm}$ の 駐車スペースでかつ前方の道路幅が $6000 \mathrm{~mm}$ の既存駐車 場エリアで行った。並列駐車実験では 全長 $8000 \mathrm{~mm}$, 全幅 $3000 \mathrm{~mm}$ の駐車スペースでかつ前方の道路幅が $6000 \mathrm{~mm}$ の駐車場エリアを設定して行った。

駐車最終目標位置・姿勢は駐車スペースの形状から予め 定まる。本実験では目標 $x$ 座標・ $y$ 座標・姿勢 $(\theta)$ に対して のずれが直角駐車の場合 $\pm 300 \mathrm{~mm}, \pm 300 \mathrm{~mm}, \pm 5^{\circ}$, 並 列駐車の場合 $\pm 300 \mathrm{~mm}, \pm 400 \mathrm{~mm}, \pm 5^{\circ}$ 以下の場合駐車 終了指令を表示した。

20 代 50 代の, 様々な連転レベルの被験者 15 人に対し て複数回, 本システムを使用してもらい, 駐車実験を行なっ た。いずれの場合においても，駐車スペースまでの安全な ガイタンスが行なわれ駐車終了指令提示を確認した。この 実験結果からセンシングシステムで必要な精度が得られて いることが確認された。

図 13, 図 14 に直角 (横列) 駐車の場合の実験結果を, 図 15 , 図 16 に平行 (縦列) 駐車の場合の実験結果を示す。 これらの図において, 叙りつぶされている車両位圆は車両 の停止位置であり，ここでギアおよびステアリング操作を 行う。

提案された手法を用いることで経路からのずれが存在し ても可能な限り一回の切り返しでガイダンスを行うことが 


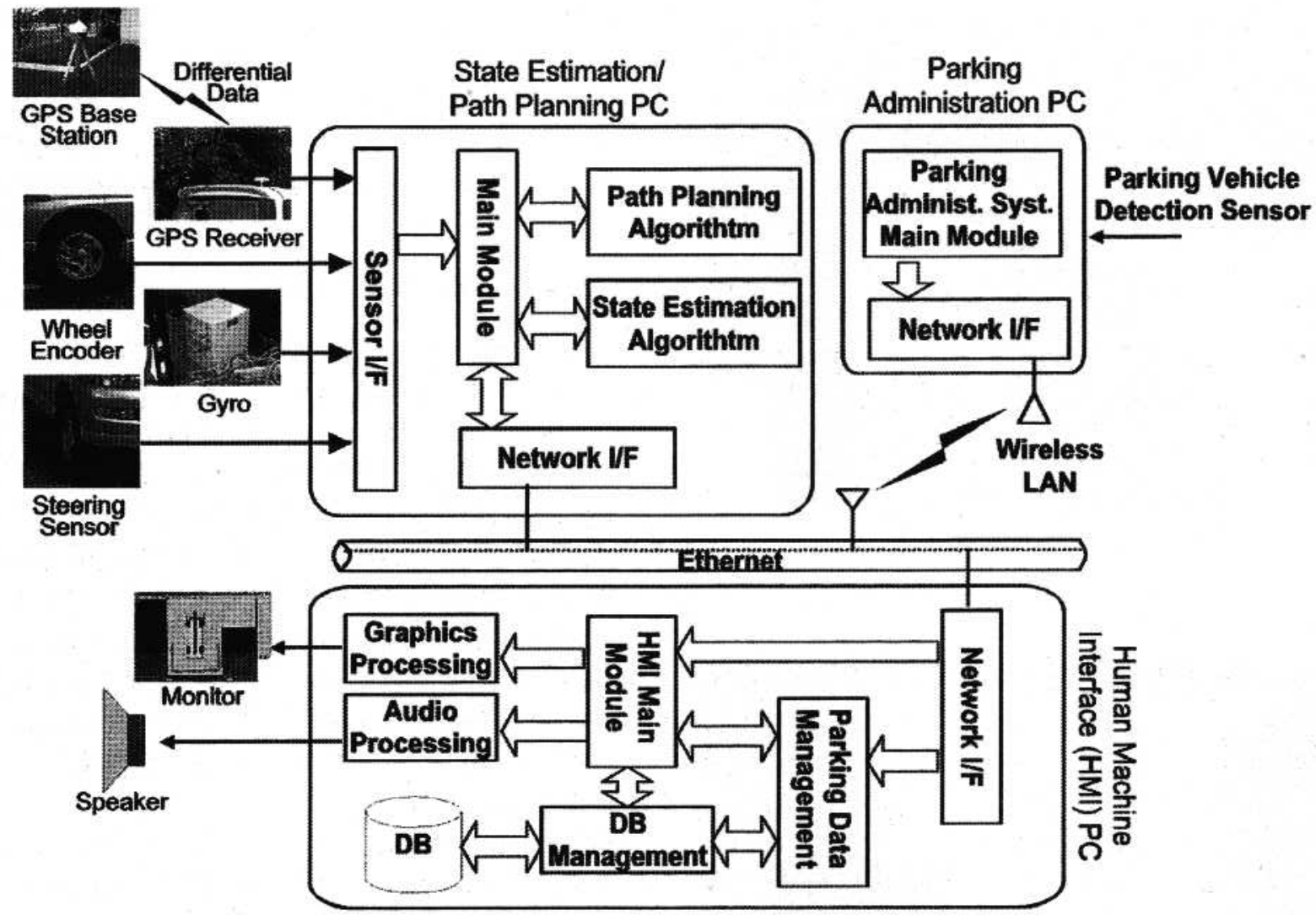

図 11 システム構成

Fig. 11. System Composition.

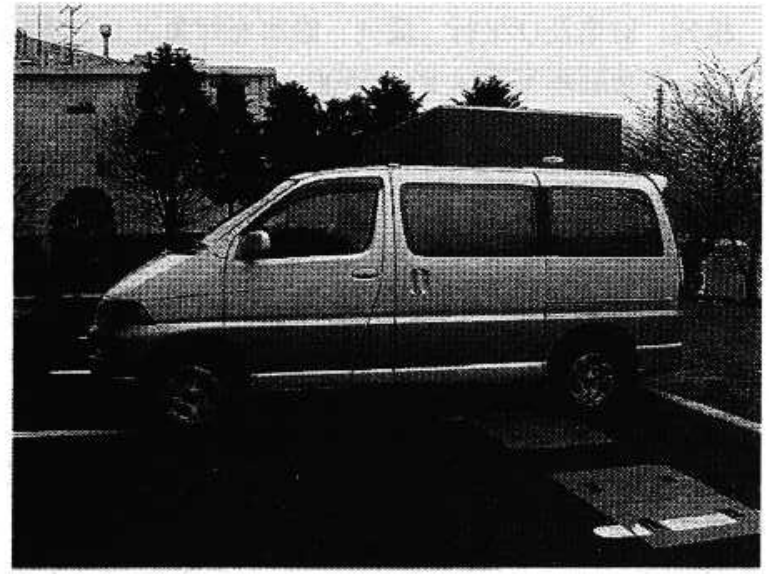

図 12 実験用車両

Fig. 12. Experimental Vehicle.

できる。このため, 実験ではほとんどのケースにおいて一回 の切り返しで一回で図 13 , 図 15 に類似した経路の堅車が行 われたことが確認された。図 13 の直角駐車ガイダンスの場 合では二つの直線 ([a] 全長 $5200 \mathrm{~mm}$, [d] 全長 $3400 \mathrm{~mm}$ ) と二つの円弧 ([b] 半径 $5500 \mathrm{~mm}$ と全長 $2800 \mathrm{~mm},[\mathrm{c}]$ 半 径 $5200 \mathrm{~mm}$ と全長 $4100 \mathrm{~mm}$ ) で檴成された経路によって 駐車が行われた。眓 15 の平行駐車ガイダンスの場合には 三つの円弧 ([a] 半径 $15700 \mathrm{~mm}$ と全長 $5800 \mathrm{~mm}$, [b] 半

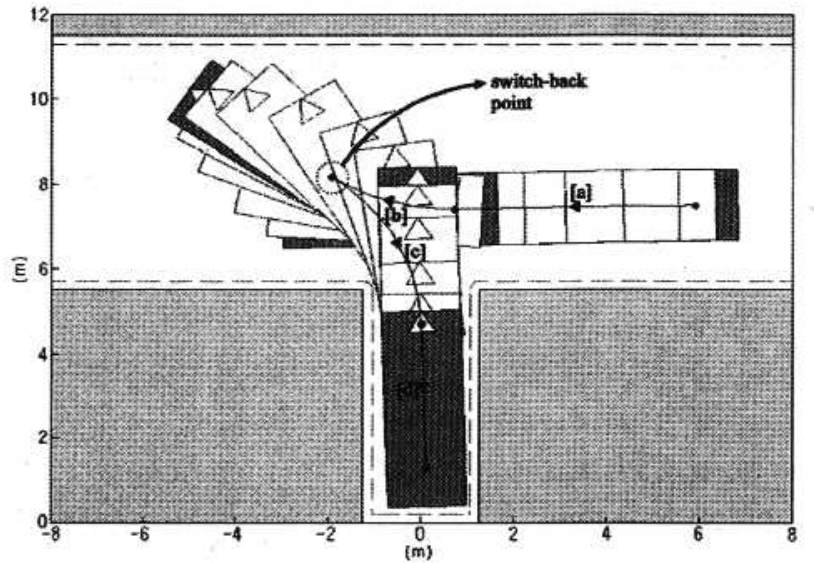

図 13 直角 (横列) 駐車の場合の実験結果 (1 回切り返し)

Fig. 13. Result of row parking case (single switch back).

径 $5400 \mathrm{~mm}$ と全長 $3300 \mathrm{~mm}$, [c] 半径 $5200 \mathrm{~mm}$ と全長 $5100 \mathrm{~mm})$ と一つの直線（[d] 全長 $1200 \mathrm{~mm}$ ) で構成され た経路によって酫車が行われた。

全駐車の約 $20 \%$ の場合では図 14 , 図 16 のように複数 $(2$ 回から 3 回）の切り返し指示が必要となる場合を観測され た。これはドライバのハンドル操作エラーとセンサキャリ ブレーションの不十分性によるものである。 


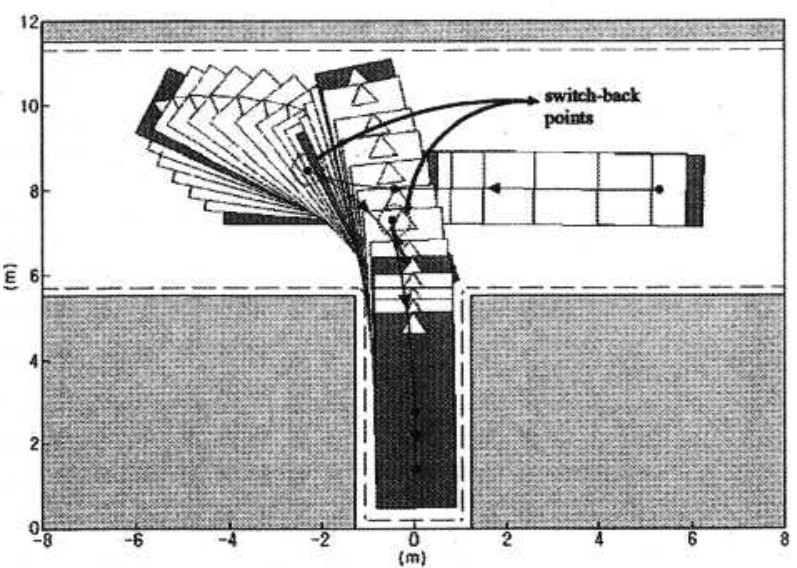

図 14 直角 (横列) 駐車の場合の実験結果 (複数切り返し)

Fig. 14. Result of row parking case (multiple switch back).

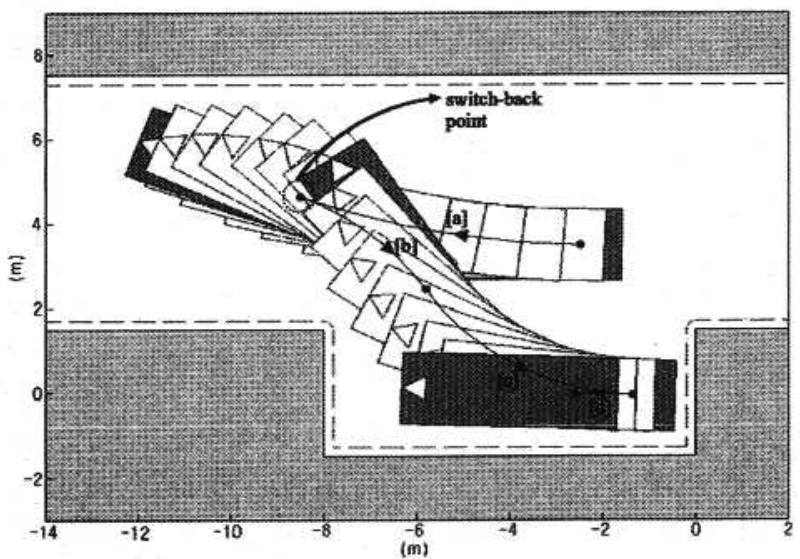

図 15 平行 (縦列) 駐車の場合の実驗結果 (1 回切り返し)

Fig. 15. Result of lane parking case (single switch back).

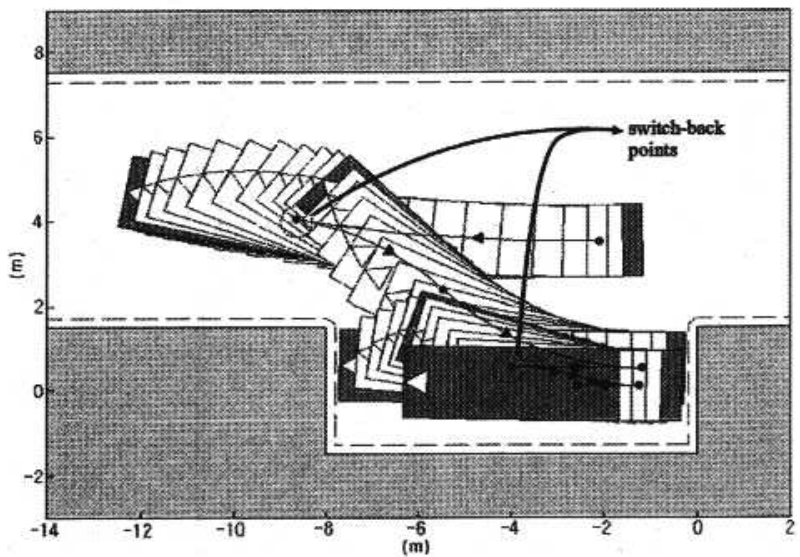

図 16 平行 (縦列) 駐車の場合の実験結果 (複数切り返し)

Fig. 16. Result of lane parking case (multiple switch back).
これらの結果は経路からのずれが大きい場合でも PPR による経路生成手法を用いることで最少回数の操作による ガイダンスが実現されていることを示している。本ガイダ ンスシステムの有効性は特に運転レベルの低い被験者にお いて顕著で, その場合駐車時間の短縮と操作回数の隇少が 確認された。

6. まとめ

本研究では, 運転支援システムの一環として, ヒューマ ンガイダンスを用いた駐車支援システムを開発した。また， 駐車支援システム実現のため, 駐車場管理システム, セン サシステム，ヒューマンガイダンスシステムを構築した。

ヒューマンガイダンスのために経路生成アルゴリズムと ヒューマンインターフェースによるアーキテクチャを提案 し，このアーキテクチャを用いた駐車支援システムの各シ ステムの設計と構築について述べた。

新たに開発された経路生成アルゴリズムにより，ドライ バが追従しやすく，かつドライバに指示しやすい経路を生 成することが叮能となった。具体的には, PPRを方向転換 点または経由点として利用する手法を提案し, 直線と円弧だ けで構成される経路及び運転操作情報を生成よた。ヒュー マンインターフェースには, 視覚扔よび聴営インターフェー スを用い, 経路生成アルゴリスムが生成した経路及び運転 操作情報をドライバの操作を妨げることなく分かりやすい 形で提供した。

また，本駐車支援システムを利用した実際の毀車実験に より, 直角 (横列) 駐車及び平行（縦列）駐車に扔いて安 全に駐車を行えることを実証した。

プロトタイプの開発と実験を行って判明した点, 今後の 研究について得られた知見について以下に述べる。

・從来の駐車システムでは車両後方の情報のみを用いて 駐車動作の一部（後進動作）の支援に限定されるため, ガイダンスを開始する際の初期停止位置は運転者が独 自に選択しなければならない。この場合, 最終的に駐 車することが困難または不可能な初期位置に車雨が停 止する可能性がある。本システムでは駐車エリア周辺 の幾何学条件 (車軕後方の情報のみでなく駐車エリア 前の道幅等も含める）を使用して全プロセスのガイダ ンスを行っているためこの問題が発生しない。このよ うに全プロセスを支援しているため，初心者等から従 来のシステムと比較して本システムでの駐車が容易で あるという評俩が得られたと思われる。

また従来のシステムと異なって定量的な指令を含め たガイダンス方法 1) の応用もこの䚵侕の要因だと思 われる。

・本駐車ガイダンスシステムを利用して安全に駐車を行 えることを実証したが, 熟練したドライバ, また複数 回システムを使用してシステムに慣れたドライバには 現在の駐車ガイダンスは朵長すぎて苛立つ感がある。 今後異なる運転レベルに対応し,ドライバの慣れに伴 
い駐車ガイダンスシステム自体が進化することが望ま しい。

・現在のセンサ技術でガイダンスシステム（高精度操作 を必要とするシステムも含めて）に必要な精度の実現 が可能であることを確認した。

さらにガイタンスシステムでは複数の状態変数が必 要となることも確認した。この要求を考虑して安全性 を確保するためには, 複数センサデー夕融合を用いた センシングシステムが適している。

・提案されたヒューマンガイダンスシステムアーキテク チャは本駐車支援システム構築には十分であった。し かしながらガイダンスアーキテクチャを一般化するた めには，提案されたアーキテクチャを改善する必要が ある。特に様々な運転レベルのドライバ, 複雑なアシ スタンスモード問遷移等へ対応する必要があり，ドラ イバインザループシステムのために提案された手法 ${ }^{(13)}$ 等の導入が考えられる。

・ガイダンスシステムは経路生成とヒューマンインター フェースの密接な結合により実現される。そのため経 路生成アルゴリズムは従来手法で考慮されている要求 に加えて新たな要因を考慮して設計する必要がある。

他システムへ応用するときシステムの要求によって は本稿で提案された経路生成方法の改善が必要となる。 まず熟練したドライバに対して，または複雑な状況下 でガイダンス方法 2) が実施不可能な運転シナリオ (障 害物回避等）で支援を実現するためガイダンス方法 3) (pag.3) に対応するための改善の必要性が考えられる。 また動的なシナリ才（複数車画が存在するなかの車線変 更等）に対応出来るための改善の必要性も考えられる。

・インターフェースの設計はシステムバフォーマンスに 対して影響を与えることが確認された。また, 音声イ ンターフェースを用いることでドライバの負担を軽減 して, 周辺監視を踈かにせずに駐車のための操作を行 なうことが可能となることを確琾した。このため, 安 全性が非常に重要な車雨のヒューマンインターフェー スでは，音声支援を含めたシステムが適していること が分かった。

(平成 14 年 4 月 3 日受付, 平成 14 年 9 月 24 日再受付)

\section{文献}

(1) I.E. Paromtchik and C. Laugier: "Autonomous Parallel Parking of a Nonholonomic Vehicle", Proceedings of the IEEE Intelligent Vehicles Symposium, pp.13-18, Tokyo, Japan, Sep. (1996)

(2) C.W. Cheng, S.J. Chang, and T.H.S. Li: "Parallel-Parking Control of Autonomous Mobile Robot", Proc. International Conference on Industrial electronics, and Control, and Instrumentation, pp.1299-1304 (1997)

(3) S.J. Chang, C.W. Cheng, and T.H.S. Li: "Design and Implementation of Fuzzy Garage-Parking Control for A PC-based Model Car", Proc. International Conference on Industrial electronics, and Control, and Instrumentation, pp.13051310 (1997)
(4) M. Ohkita, H. Miyata, M.P. Miura, and H. Kouno: "Traveling experiment of an autonomous mobile robot for a flush parking", Proc. 2nd IEEE International Conference on Fuzzy Syst., vol.1, pp.327 332 (1993)

(5) M. Wada, K.S. Yoon, H. Hashimoto, and S. Matsuda: "Parking Assistance System based on High Accuracy Position Sensing", Proc. IEEE International Vehicle Electronics Conf., pp.468 473 (1999)

（6）池上孝則・大闺成夫：「距離做ポテンシャルに基つくく経路探索1, 日 本ロボット学会第 8 回学学術講演会子稿集, pp.195-198 (1990)

(7) J.C. Latombe: Robot Motion Planning, Kluwer Academic Publishers (1996)

(8) J.O. Kim and P. Khosla: "Real-Time Obstacle Avoidance Using Harmonic Potential Functions", IEEE/RSJ international Conference on Robotics and Automation, pp.790 796, Sacremento, CA, April, (1991)

（9）安部正人：自動車の連動と湖御, 山海堂 (1992)

(10) J. Guldner, V.I. Utkin, and H. Hashimoto: "Robot Obstacle Avoidance in n-Dimensional Space Using Planar Harmonic Artificial Potential Fields", Trans. ASME- Journal of Dynamic Syst., Measurement, and Control, Vol.119, No.2, pp.160-166, June (1997)

(11) M. Wada, K.S. Yoon, and H. Hashimoto: "High Accuracy Road Vehicle State Estimation Using Extended Kalman Filter", Proc. 3rd IEEE International Conference on Intelligent Transportation Systems (2000)

(12) HORB: http://www.horb.org/

(13) M.A. Goodrich, and E.R. Boer, "Designing human-centered automation: Tradeoffs in collision avoidance system design", IEEE Trans. Intelligent Transportation Syst., Vol.1, No.1, pp.40-54, March (2000)

\section{付 録}

\section{1. 直角駐車の PPR 演算方法}

\section{ここでは, 直角駐車の PPR 演算方法を示す。}

〈1·1〉 経路生成座標系＼cjkstart煁車ガイダンスアルゴリズム では後輪軸の中心位置 $(x, y)$ を車両位置として使用した。 また車体角として反時計方向で $X$ 軸を基準にした $\theta$ 及び $Y$ 軸を基準にした $\alpha$ を用いた。アルゴリズムで使用した 座標系と駐車場パラメー夕を付図 1 に示す。

〈1・2〉パラメータ記号アルゴリズムで用いられるパ ラメータの記号は以下の通りである。

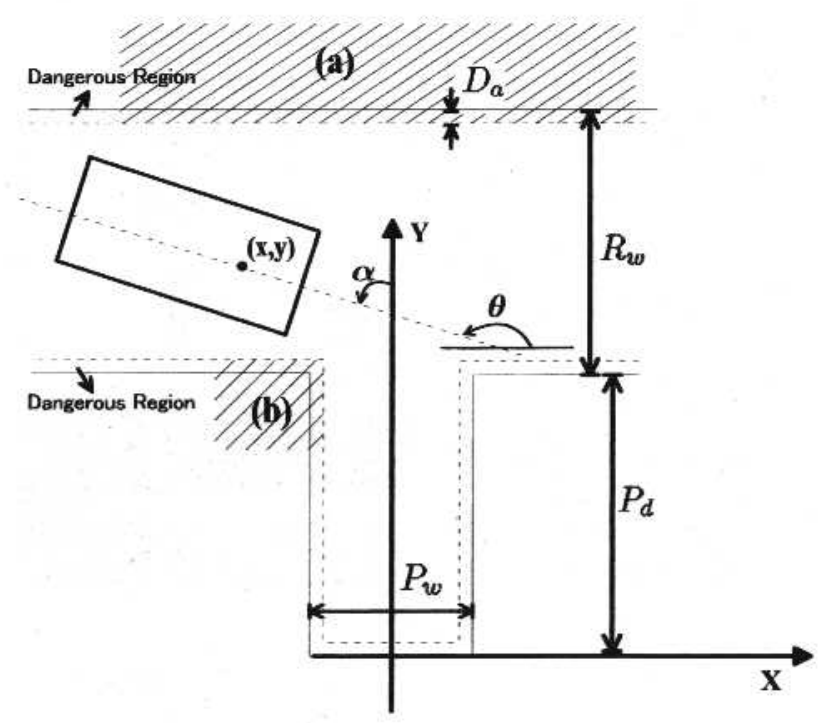

付図 1 駐車エリア座標系

app. Fig. 1. Parking area coordinate system. 
$x$ : 駐車エリア座標系の $X$ 軸方向車両位置 $y$ : 駐車エリア座標系の $Y$ 軸方向車両位䈯

$\theta: X$ 軸を基隻とした車体角 $(\theta=\alpha+\pi / 2)$

$\alpha: Y$ 軸を基準とした車体角 $(\alpha=\theta-\pi / 2)$

$D_{a}$ : 駐車エリア, 通路周辺の危険領域幅

$C_{a}$ : 車両の後トレッドから前バンパーまでの長さ

$C_{c}:$ 車体幅の半分の長さ

$R_{w}$ ：駐車エリア前の道幅

$P_{d}$ : 駐車エリアの長さ

$P_{w}:$ 駐車エリアの幅

$y_{u}: \mathrm{PPR}$ の上境界

$x_{r}: \mathrm{PPR}$ の右境界

$R_{\min }$ : 最小回転半径

〈1·3〉 PPR 演算方法 車両が付図 1 のように後進 しながら駐車を行うと仮定する。

各PPR 角度と駐車エリア反対側の危険領域 (a) に突入 しない条件で PPR 上限界線が決まる。車体角が可能領域 角度で (a) の境界線を接点とする車両の $y$ 座標から PPR の上限界線式

$$
\begin{aligned}
y \leq & y_{u} \\
y_{u}= & R_{w}+P_{d}-D_{a}-\sqrt{C_{a}^{2}+C_{c}^{2}} \\
& \sin \left(-\tan ^{-1}\left(\frac{C_{c}}{C_{a}}\right)+\theta\right) \ldots \ldots \cdots \cdots
\end{aligned}
$$

が得られる。

また各可能領域角度と最小回転半径で駐車スペース中心 線に到達可能である条件で PPR 右限界線が定まる。駐車 スペース中心線から最小半径で移動したとき車体角が叮能 領域角度に等しい位置の $x$ 座標から PPR の右限界線式

$$
\begin{aligned}
x & \leq x_{r} \\
x_{r} & =-\operatorname{sgn}(\alpha) R_{\min }(1-\cos (\alpha))
\end{aligned}
$$

が得られる。

PPR の左傾斜境界線は各可能領域角度と眭車エリア左 コーナー (b) に衝突せず駐車スペース中心線に到達可能であ るという条件で定まる。可能領域角度 $\alpha$ を固定すると駐車 スペース中心線に到達可能な半径が $x$ 座標の関数として定
まる。左コーナー (b) に衝突しない条件を表す式に半径関 数を導人し得られた $y$ 座標から次の左傾斜境界線の式が得 られる。

$$
\frac{y \geq P_{d}-\frac{x}{\sin \alpha}-\frac{x}{\tan \alpha}-\sqrt{2\left(\frac{P_{w}}{2}-C_{c}-D_{a}\right)}}{\left.\left(\frac{-x}{\tan \frac{\alpha}{2} \sin \alpha}-\frac{\frac{P_{w}}{2}-C_{c}+D_{a}}{2}-C_{c}\right) \ldots \ldots \text { (付 } 3\right)}
$$

以上の式付 1 , 付 2 , 付 3 を満足する点の集合が PPR を 㯵成する。

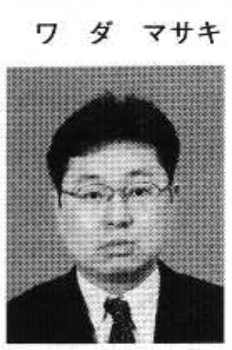

（非会只） 1971 年 3 月 31 日坐。1994 年 12 月 Instituto Tecnologico de Aeronautica 大学工学 部電子工学科卒業。1997 年 3 月同大学大学院士 学系研究科需子情報士：学尃玫修上課程修厂。1997 年 4 月東京大学大学院工学系研究科電子情報工学 博士諜程人学, 現在に至る。制御理㖮, 推定理淪, ITS の研究に徉事。

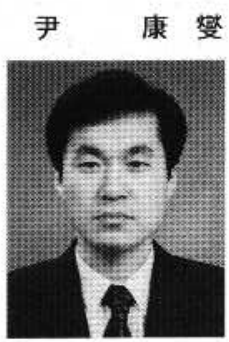

(非会員) 1963 年 9 月 15 日生。 1986 年 2 月釡 山大学工学部精密機械工学科卒業。1997 年 2 月 同大学大学院精密機械厂学守攻博士昩程修了工学 博士。同年 9 月東京大学生産技術研究所客員研究 具。2000 年 3 月大邱大学自動車産業機械工学部 講例, 現在に至る。制御工学, Robotics 及びITS の研究に従事。

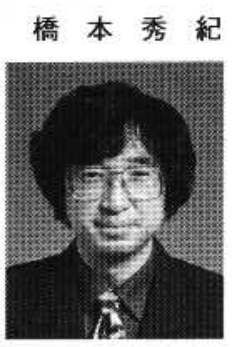

（正员） 1957 年 8 月 15 日生。1981 年 3 月東京 大学工学部電気工学科卒業。1987 年 3 月同大学 人学院士学系研究科電気工学専攻博士課程修了工: 学博士。同年 4 月同大学講師。生産技術研究所勤 務。1990 年同大学助教授, 現在に至る。1989-90 年 MIT 客具研究員 (LIDS, LEES)。知的制御シ ステム, 制御さ学, Robotics 及び ITS の研究に 従事。 